\title{
About Some Astronomical Instruments from Batthyanian Observatory in Alba Iulia
}

\author{
Elvira Botez and Tiberiu Oproiu \\ Astronomical Observatory Cluj-Napoca, Str. Ciresilor 19, 3400 \\ Cluj-Napoca, ROMANIA
}

\begin{abstract}
Built toward the end of the 18th century on the last floor of a former Trinitarian church, the Astronomical Observatory in Alba Iulia (Romania) was equipped with instruments brought from Vienna and it was in activity until 1860. A description of the astronomical instruments of those existing at present is given.
\end{abstract}

Alba Iulia, the ancient Roman Apulum, preserves in one of its buildings one of the oldest astronomical observatories in Romania. The initial building - church of a Trinitarian order - built at the dawn of the 18th century would be taken over by Transylvania's Bishop IGNATIUS BATTHYANI (1741-1798) after the abolition of the order towards the end of the century. A personality with advanced views who through his activity tried to put the material basis of a high scientifical life in Transylvania, the bishop would order some changes, the church being thus given a new destination: library and astronomical observatory. In the nave and apse there would be the library and in the superior part, on the flat roof of the church there would be raised a central square room for the astronomical instruments, with three windows and doors on each side, flanked to the east and west by two small towers and having above the southern facade the inscription: VRANIAE / POSVIT / C(OMES) IG(NATIUS) DE BATTHYAN / EPISC(OPUS) TRANSILV(ANIAE) / 1794. Nowadays the roof of the observatory is delimited to the south by an arched fronton with the inscription URANIAE on it. To the north of the central room, a space protected by a roof truss housed the meteorological instruments. The room itself gets a specific decoration: on the one hand a series of portraits of some personalities in the history of astronomy, under the form of mural medallions placed below the ceiling, whose figures can be easily identified with the help of the inscriptions (Platon, Iulius Caesar, Ulug Begh, etc), and on the other hand uninscribed oil portraits which are exhibited above some footings painted on the walls of the room, representing Ptolemy, Tycho Brahe and Kepler (presently deposited in the library's storage). The mural decoration was completed with the signs of the zodiac and of the planets, while the crown of the northern door had the carved heraldic device of Ignatius Batthyani. The ceiling was plated with paintings on wood representing compositions with mythological characters that had played an important role in the development of astrology, with Urania in the central frame. Through a system of bearings and pulley the frames of the ceiling, each taken separately, could be removed together with the roof that protected them so as to make possible the observations in angles bigger than $60^{\circ}$. Inside the room, a central part was delimited by poles which supported the mobile ceiling, 
where they placed the mobile instruments. The floor was paved with plates in two colours, arranged in diagonal line. Nowadays the room has a wooden floor, the supporting poles are missing and the ceiling is an ordinary one.

After its setting up, the observatory would be equipped with astronomical and meteorological instruments brought from a suppressed Jesuitic College in Vienna by ANTONIUS MARTONFI who would be its first astronomer. This one, professor of Ecclesiastical Law (1782-1788) at the Bethlenian College, was sent by Batthyani to Vienna to study astronomy under the guidance of Maximilian Hell, the well known participant in the northward expedition of observing the transit of Venus in 1769 and director of Vienna Astronomical Observatory. Coming back to Alba Iulia in 1792 he was entrusted the management of the observatory which started working in 1795 . In 1798 Antonius Martonfi presbiter secularis, philosophiae doctor, speculae ejusdem director et astronomus published the book INITIA / ASTRONOMICA / SPECULAE BATTHYANIANAE / ALBENSIS IN TRANSILVANIA, the first volume of the six he had planned to write, but his early death in 1799 stopped the fulfilment of this plan.

Collaborator and successor of Martonfi was Josephus Bede, who was followed by Emericus Kovats and later by Moyses Keserii. In 1860 the job of canonical astronomer was cancelled, the Diocese being then interested only in the library.

At present time in this building only the library is functional, preserving a valuable treasure of manuscripts (among which Codex Aureus, a Carolingian manuscript of twelve centuries old), incunabula, ancient books and documents.

Out of Martonfi's work, a real (visiting) card of the Astronomical Observatory, we may find out many details regarding its building, the description of the astronomical and meteorological instruments as well as their use.

We try below to partially reconstruct the assembly of astronomical instruments in this observatory. In the central room, from the gnomon, there is preserved only the plumb-line and the meridian thread (line) that went from the north to the south of the room, being sheltered under a trap door.

Next to the west side, on a wall of dimensions suitable for the aim, oriented towards the meridian and ended to the south in front of a window, there is fitted up the mural quadrant (Fig. 1a) with the help of fastening elements tied to the bars which assure the rigidity of its arc. This has the radius of $2 \mathrm{~m}$ and its limb equipped with vernier solidary to the refractor is graduated from $0^{\circ}$ to $90^{\circ}$. The refractor has $4 \mathrm{~cm}$ aperture and its tube is $203 \mathrm{~cm}$ long; in its focal plane it is equipped with an eyepiece micrometer.

The mobile quadrant (Fig. 1b) has as equipment: arc of $90^{\circ}$ with 4 rectangular bars assuring its rigidity, plumb-line protected in a box, eyepiece micrometer in the focal plane of the refractor, but also it has a mobile tripodal stand, a horizontal circle with the possibility for the refractor to be moved in azimuth and an alidade solidary to the refractor carrying the external micrometer. The refractor has the aperture of $5 \mathrm{~cm}$, and the tube length of $125 \mathrm{~cm}$. The radius of the arc is of $105 \mathrm{~cm}$ and on the inscription at the bottom end of this one can read: Johann/ Linterer/ in/Wienn/ 1793.

The western addition of the central room shelters the transit instrument (Fig. 1c); to avoid the trepidations its rotational axis is fastened to two massive poles, the northern and southern windows and the mobile roof offering visibility 
of a strip of sky along the meridian. The horizontality of the axis is made with the help of the water level. There are conterweights to eliminate the flexions of the refractor tube whose length is $125 \mathrm{~cm}$. The refractor has the aperture of $8.5 \mathrm{~cm}$ and an eyepiece micrometer in the focal plane. Its position can be read at the meridian circle with the diameter of $74 \mathrm{~cm}$. At the eyepiece end of the refractor tube: K.K.polytechn.Institut in Wien.Chr.Starke is inscribed, without mentioning the year of manufacturing.

The equipment of the meridian room was completed by a sidereal pendulum clock fastened on its southern wall. On its dial one can read the name of its builder (Fig. 1d). Other two pendulum clocks whose former place is not known, are today in a room on the groundfloor of the library. They have been well preserved and can be easily put into use.

Beside the three observing instruments whose use is especially astrometrical, the observatory also had refractors of different dimensions with metal tripodal stands and brass tubes from which we illustrate: 1) a refractor with tube length of $35 \mathrm{~cm}$ and aperture of $3,5 \mathrm{~cm}$ having inscribed on the stand: Andreas / Schulz / fecit; 2) a refractor with tube length of $40 \mathrm{~cm}$, aperture of $5 \mathrm{~cm}$, Dollond London objective and equatorial mounting, and 3) a refractor with tube length of $103 \mathrm{~cm}$ and aperture of $9 \mathrm{~cm}$, equipped with a device for sharp adjustment in height and azimuth, having inscribed on its tube: Instituto astronomico diocesano AD 1858 / Ludovicus Haynald / Episcopus Transilvaniensis / Plössl in Wien. In the first floor room of the library where these refractors are preserved there are also disparate pieces of instruments as well as a Newtonian telescope with a wooden octagonal tube, from whose optical part only the eyepiece has been preserved.

The endowment of the observatory also contained celestial and terrestrial globes which are now preserved in this room and in the storage. From the tablets (labels) on the celestial globes we can realize Maximilian Hell's contribution to their drawing up. The technical execution was made in 1790 at Nürnberg by I.G. Klinger, Frauenholz \& Klinger and I.B. Bauer. At the same time the terrestrial globes were also made in Nürnberg with the help of geographical maps drawn up after the expeditions of the great explorers of the 18th century. They show us the world known at the time the first meridian passed through the Faeroe Islands.

The whole inventory of the Batthyanian Astronomical Observatory is of a real historical interest. It preserves the material basis of an observatory at the end of the 18th century which reveals us the level of development of processing brass pieces, especially circles, the precision of tracing the divisions as well as the perfection reached by optical industry at the beginning of the industrial revolution. Its apparatus, after a work of restoration done in the 1970s and a negligible wear is in a good condition.

Very little is known about the research activity which was carried out during the few decades when the observatory worked. As Martonfi had mentioned in the introduction of his work, the results of the research were to be published in the 6 th volume.

A study of the astronomical archives preserved in the Batthyaneum Library could shed some light on the history of this observatory which has been so little 

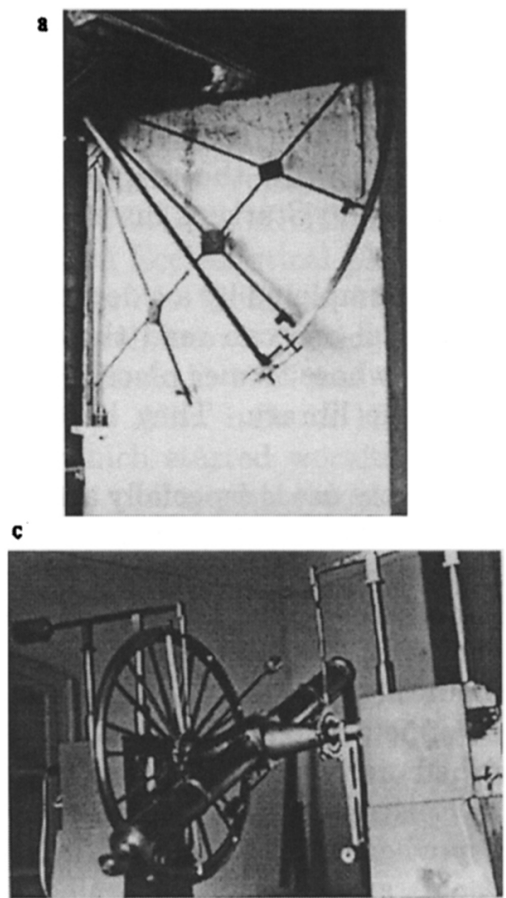

b
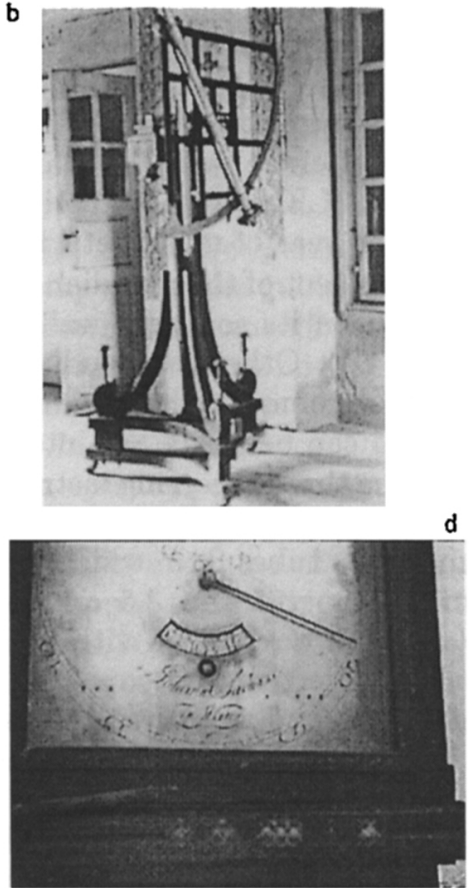

Figure $1 . \quad$ a) mural quadrant; b) mobile quadrant; c) transit instrument; d) pendulum clock detail.

studied so far and could integrate it into the circulation of scientific and cultural values of the decades when it has been in activity.

\section{References}

Bostan, I., \& Mioc, V. 1987, Figuri ale istoriei astronomiei la Observatorul Batthyaneum de la Alba Iulia, Progrese in astronomie si stiinte spatiale, Bucuresti, p.81 (in romanian)

Ionescu, I. 1939/1940, Observatorul Astronomic Batthyanian din Alba Iulia, Gazeta Matematica, vol.45, p.617 (in romanian)

Kovács, A. 1992, Observatorul Astronomic Batthyaneum de la Alba Iulia: un program decorativ putin cunoscut, Ars Transilvaniae, vol.2, p.23 (in romanian)

Trifu, M., \& Alexievici, E. 1996, Folosirea zestrei Observatorului Astronomic Batthyaneum din Alba Iulia in predarea astronomiei, Didactica matematicii, vol. 12, p.293 (in romanian)

Wellmann, V., Valori uitate ale patrimoniului stiintific si cultural: Observatorul Astronomic (Specula) de la Alba Iulia din 1794, private paper 